\title{
CONSERVATION STATUS OF MOSS SPECIES IN NORTHERN MARITIME ANTARCTIC BASED ON THE INDEX OF ECOLOGICAL SIGNIFICANCE
}

http://dx.doi.org/10.4322/apa.2014.063

\begin{abstract}
Filipe de Carvalho Victoria ${ }^{1, *}$, Margéli Pereira de Albuquerque ${ }^{1}$, Cristiane Barbosa D'Oliveira ${ }^{1}$, Antonio Batista Pereira ${ }^{1}$
\end{abstract}

${ }^{1}$ Universidade Federal do Pampa - UNIPAMPA, Av. Antonio Trilha, 1847, CEP 97300-000, São Gabriel, RS, Brazil *e-mail: filipevictoria@gmail.com

\begin{abstract}
The aim of this work was to verify moss conservation status on ice-free areas of northern Maritime Antarctic, including data of Elephant Island, King George Island and Deception Island. The study started with the classification and description of the plant communities based primarily on phytosociological and biodiversity data. All records were obtained from 1991-1992 to 2003-2004 austral summers. The coverage degree and frequency of each species found was used to calculate the index of ecological significance. 22 most frequent species based on all island records were found. The most important species in both studied areas were Sanionia uncinata (Hedw.) Loeske, Polytrichastrum alpinum (Hedw.) G. L. Smith, Bartramia patens Brid., respectively, occurring in all the studied islands. These results demonstrate the fragility of plant communities in Maritime Antarctic, based on the low frequency and coverage of most species known to this area.
\end{abstract}

Keyword: Bryophyta, ice-free areas, plant communities

\section{Introduction}

Since 1940 there has been evidence through monitoring and observation of the global warming effect on the plant species of Maritime Antarctic, mainly related to the oscillations in the percentages of plant coverage (Lewis-Smith, 2001). An important tool to study these fluctuations in bryophytes populations was idealized by Lara \& Mazimpaka (1998). These authors developed the Index of Ecological Significance (IES), which compares the frequency and abundance of data to determine the importance of the species in a studied area. The index can be applied for moss conservation and phytosociological studies and for the classification of threatened species (Hallingbäck \& Hodgetts, 2000), proposed by the International Union for Conservation of Nature (IUCN). Furthermore to reflect the importance of the particular species in plant formation, which also shows the degree of association within species in the sample, such is the degree of importance of maintaining this formation. If many species are associated with the dominant species of a formation, thus invariably they reflect the dependence of the associated species, and if the dominant species is threatened, their dependents also will be (Lewis-Smith, 2001).

In order to complement the knowledge of plant communities in the ice-free areas of Admiralty Bay, are presented the conservation status of mosses based in several phytosociological studies developed in the Maritime Antarctic.

\section{Materials and Methods}

The data obtained in the phytosociological approaches since 1991/1992 up to 2003/2004 austral summers, were compiled to verify the most frequent species found in the plant communities from northern Maritime Antarctic. Data was analyzed from some four islands from the South Shetland Islands, as follows: Elephant Island (1991/1992 summer); King George Island (2003/2004, 2004/2005 summers) and Deception Island (1993/1994). High coverage moss species or dominant lichen species were sampled using the usual collection methods. The identification of the species was 
based on specialized literature, such as Ochyra et al. (2008), Pereira \& Putzke (1994) and Putzke \& Pereira (2001). The index of ecological significance (IES) was calculated based on the Lara \& Marzimpaka (1998), subsequently Victoria \& Pereira (2007).

\section{Results}

Of the 102 moss species confirmed by Ochyra et al. (2008) for Antarctica, 22 of the most important moss species to northern Maritime Antarctic were found. From our data it was possible to verify the occurrence of Sanionia uncinata (Hedw.) Loske as the most frequent species in the three island communities is analyzed in (Tables 1 to 3 ). However with the IES of each species it was possible verify the other dominant species varieties of both islands (Figure 1). Polytrichastrum alpinum (Hedw.) G.L. Smith was observed as the second most important species in the ice-free areas of King George and Deception Islands.

The IES also indicates the degree of colonization of a determined species in the sample (Lara \& Mazimpaka, 1998) which can also suggest the effect of variations of species occurrences related to the available substrata. Thus, if a species depends on a rich matter substrata and those are unavailable in that region that species will decline due to the relevant substrata being missing (Victoria et al., 2006). Probably, for the regions where the terrains are composed of a lower fraction of organic matter only a few species included in the most important species list were found. This is the case of Deception Island, where, due the predominant volcanic substrata, only four species with significant index values (Table 3 ) were found, most plant communities being

Table 1. The species have more and less IES in the phytosociological analyzes made in Elephant Island in the year 1992. $F(\%)=$ species frequency in 240 sampled quadrats; $C=$ mean cover degree of each species on the samples. IES = species index of ecological importance in the total sampling.

\begin{tabular}{lccc}
\multicolumn{1}{c}{ Species } & F & C & IES \\
\hline Sanionia uncinata (Hedw.) Loeske & 68.45 & 1.76 & 189.24 \\
Bartramia patens Brid. & 1.60 & 0.02 & 1.63 \\
Ceratodon purpureus (Hedw.) Brid. & 1.07 & 0.01 & 1.08 \\
$\begin{array}{l}\text { Brachythecium austrosalebrosum } \\
\text { (Müll. Hal.) Paris }\end{array}$ & 1.07 & 0.02 & 1.09 \\
$\begin{array}{l}\text { Pohlia nutans (Hedw.) Lindb } \\
\text { Pohlia cruda (Hedw.) Lindb. }\end{array}$ & 0.53 & 0.01 & 0.54 \\
\hline
\end{tabular}

Table 2. The species have more and less IES in the phytossociological analyzes made in King George Island in the austral summers 2003/2004 and $2004 / 2005$. $F(\%)=$ species frequency in 560 sampled quadrats; $C=$ mean cover degree of each species on the samples; IES = species index of ecological importance in the total sampling.

\begin{tabular}{|c|c|c|c|}
\hline Species & $\begin{array}{c}F \\
(\%)\end{array}$ & C & IES \\
\hline Sanionia uncinata (Hedw.) Loeske & 57,87 & 2,7 & 215,20 \\
\hline Polytrichastrum alpinum(Hedw.) G.L. Sm & 31,86 & 3,8 & 153,54 \\
\hline $\begin{array}{l}\text { Ptychostomum pseudotriquetrum } \\
\text { (Hedw.) P. Gaertn., B. Mey. \& Scherb. }\end{array}$ & 27,9 & 0,9 & 53,3 \\
\hline Polytrichum juniperinum Hedw. & 11,36 & 2,02 & 34,3 \\
\hline Andreaea gainii Cardot & 14,96 & 0,6 & 24,54 \\
\hline Syntrichia princeps (De Not.) Mitt. & 7,69 & 1,98 & 22,96 \\
\hline Pohlia cruda (Hedw.) Lindb. & 2,28 & 0,15 & 2,03 \\
\hline Bartramia patens Brid. & 1,71 & 0,6 & 2,03 \\
\hline Bryum pallescens Schleich. ex Schwägr. & 1,47 & 0,38 & 2,03 \\
\hline $\begin{array}{l}\text { Schistidium antarctici (Cardot) } \\
\text { L.I. Savicz \& Smirnova }\end{array}$ & 1,33 & 0,36 & 1,87 \\
\hline $\begin{array}{l}\text { Chorisodontium aciphyllum } \\
\text { (Hook. f. \& Wilson) Broth. }\end{array}$ & 0,38 & 3,68 & 1,78 \\
\hline $\begin{array}{l}\text { Dicranoweisia brevipes (Müll. Hal.) } \\
\text { Cardot }\end{array}$ & 0,38 & 3,68 & 1,78 \\
\hline Bryum orbiculatifolium Cardot \& Broth. & 0,95 & 0,74 & 1,66 \\
\hline $\begin{array}{l}\text { Brachythecium austrosalebrosum } \\
\text { (Müll. Hal.) Paris }\end{array}$ & 0,38 & 3,36 & 1,66 \\
\hline $\begin{array}{l}\text { Pohlia drummondii (Müll. Hal.) } \\
\text { A.L. Andrews }\end{array}$ & 0,20 & 3,32 & 0,84 \\
\hline $\begin{array}{l}\text { Schistidium falcatum (Hook. f. \& Wilson) } \\
\text { B. Bremer }\end{array}$ & 0,21 & 3,33 & 0,85 \\
\hline Andreaea depressinerves Cardot & 0,19 & 3,31 & 0,83 \\
\hline Bryum archangelicum Bruch \& Schimp. & 0,19 & 3,31 & 0,83 \\
\hline Ditrichum hyalinum (Mitt.) Kuntze & 0,19 & 3,31 & 0,83 \\
\hline
\end{tabular}

Table 3. The species found in Deception Island in the phytosociological analyzes made in the year 1994. $F(\%)=$ species frequency in 284 sampled quadrats; $\mathrm{C}=$ mean cover degree of each species on the samples; IES = species index of ecological importance in the total sampling.

\begin{tabular}{|c|c|c|c|}
\hline Species & $\mathbf{F}$ & C & IES \\
\hline Sanionia uncinata (Hedw.) Loeske & 71.83 & 1.84 & 203.90 \\
\hline $\begin{array}{l}\text { Polytrichastrum alpinum (Hedw.) } \\
\text { G.L. Sm }\end{array}$ & 35.92 & 1.18 & 78.15 \\
\hline Bartramia patens Brid. & 8.10 & 0.11 & 9.01 \\
\hline $\begin{array}{l}\text { Hennediella heimii (Hedw.) R.H. } \\
\text { Zander }\end{array}$ & 5.99 & 0.09 & 6.49 \\
\hline
\end{tabular}




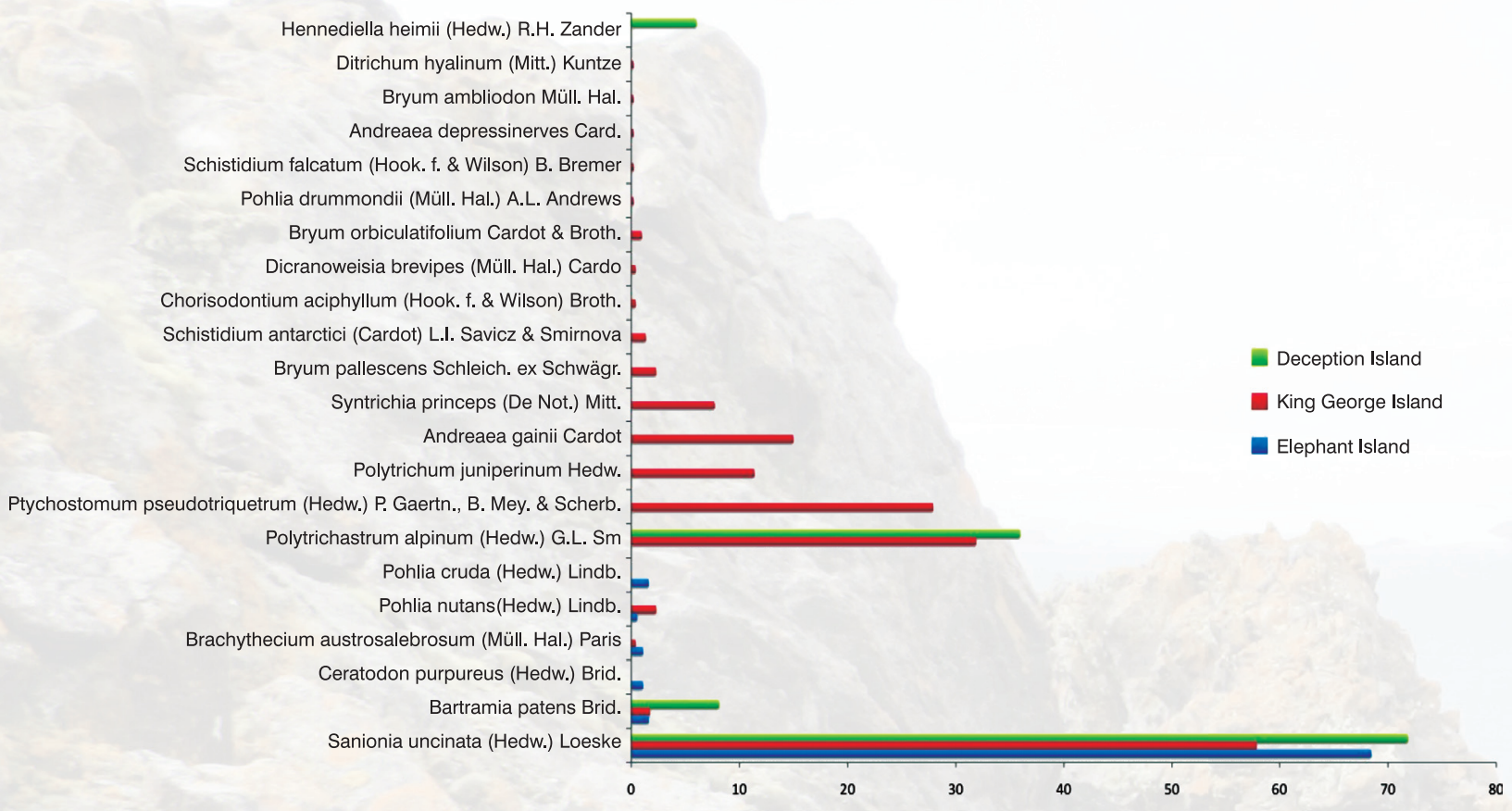

Figure 1. The most frequent moss found in northern Maritime Antarctic and their frequencies in each island sampled.

restricted to the beaches (Putzke \& Pereira, 2001) with a higher content of carbon and other nitrogen compounds. On the other hand at Elephant Island this relationship was not observed, for example, Stinker Point has higher nitrophilic soils related with the bird colonies (Pereira \& Putzke, 1994) and the most important species of the list are also few. An explanation for the latter can be closely related to the effect of winds (Putzke \& Pereira, 2001) such as in Admiralty Bay area, which is less exposed and thus shows a greater number of important species.

\section{Discussion}

Comparing the records obtained from the three islands, was observed such these corroborated with other initiatives. Most of the species are easily found in the area, but in lower coverage (IES > 50) with a lower number of species in higher abundance and coverage (Victoria et al., 2009, 2011). Ochyra (1998) reports Sanionia uncinata (Hedw.) Loeske and Polytrichastrum alpinum (Hedw.) G.L.Smith as the most abundant moss species in Maritime Antarctic, being in lower risk of threat compared with other moss species in this area. These results can suggest the sensibility of these plant communities to environmental changes, since the species were found in small patches and populations, and it showed lower resistance and resilience, wherever the interrelationships within the organisms was low (Schaefer et al., 2004). Any impacts on these species can be irreversible (Victoria \& Pereira, 2007).

For example, we can cite the most frequent Bryaceae occurrences found. Ptychostumumpseudotriquetrum (Hedw.) J.R. Spence \& H.P. Ramsay and Bryum orbiculatifolium Card. et Broth. Depend on ice-melt found in the water lines of austral summer (Allison \& Lewis-Smith, 1973; Kanda, 1986). P. pseudotrichetrum has higher abundance in our samples from King George Island and can be considered a lower degree of threatened species compared to $B$. orbiculatifolium. The size of $P$. pseudotrichetrum population provides best response in the case of fast environmental changes, perhaps an adaptative success related of a higher coverage degree (Lewis-Smith, 2001).

Victoria et al. (2011) records for small sites of Admiralty Bay area, both in the King George Island (Ulmann Point and Comandante Ferraz beach) similar results to those found for the whole South Shetlands archipelago, whereby S. uncinata also occurs in higher frequency and coverage. However with less frequency for P. alpinum P. pseudotrichetrum, for 
Ferraz beach, and Syntrichia magellanica (De Not.) Mitt, for Ulmann Point the species are the second most important for each area, perhaps because of the lower complexity of these two plant communities sampled, these communities being composed mainly of emergent species, such as these two species mentioned (Victoria et al., 2009).

Victoria \& Pereira (2007) reported the same condition for Arctowski region and Hennequin Point, both regions located in Admiralty Bay area. The other frequent moss species mentioned were found to be important species for the plant communities at Hennequin Point and in Arctowski region (Victoria \& Pereira, 2007), except for Hennediela heimii (Hedw.) Zand, which was found in higher frequency in Ferraz beach in the present study compared with other areas.

All moss species, as well the land biota found in Admiralty Bay, were directly and indirectly affected by human presence. The maintenance of scientists and military inside and outside of research stations, shelters and camps, involves high consumption of fossil combustibles and creates high residue production, causing unclear impacts on Antarctica wildlife (Olech, 1996).

\section{Conclusion}

This essay demonstrates the fragility of moss formation in the ice-free areas of northern Maritime Antarctic, such species of Bryum, Pohlia and Andreaea appear as the mostly threatened species. A descriptive data bank can collaborate for the continued monitoring of plant communities, contributing to the conservation of plant species in Admiralty Bay area. The phytosociological studies can contribute to the management of scientific activities involved with the Brazilian Antarctic Program.

\section{Acknowledgements}

This work integrates the National Institute of Science and Technology Antarctic Environmental Research (INCTAPA) that receives scientific and financial support from the National Council for Research and Development (CNPq process: $n^{\circ}$ 574018/2008-5) and Carlos Chagas Research Support Foundation of the State of Rio de Janeiro (FAPERJ $n^{\circ}$ E-16/170.023/2008). The authors also acknowledge the support of the Brazilian Ministries of Science, Technology and Innovation (MCTI), of Environment (MMA) and InterMinistry Commission for Sea Resources (CIRM), and the $\mathrm{CNPq}$ for the post-doctoral fellowship (CNPq process: $\mathrm{n}^{\circ}$ 152270/2011-6 ) to the second author.

\section{References}

Allison, J.S. \& Lewis-Smith, R.I. (1973). The vegetation of Elephant Island, South Shetland Islands. British Antarctic Survey Bulletin, 33-34:185-212.

Hallingbäck, T. \& Hodgetts, N. (2000). Mosses, liverworts \& hornworts: a status survey and conservation action plan for bryophytes. IUCN, Gland. $106 \mathrm{p}$.

Kanda, H. (1986). Moss communities in some ice-free areas along the Söya Coast, East Antarctica. Memoirs of Natural. Institute of Polar Research, Special Issue, 44: 229-240.

Lara, F. \& Mazimpaka, V. (1998). Sucession of epiphytic bryophytes in a Quercus pyrenaica forest from Spanish Central Range (Iberian Peninsula). Nova Hedwigia, 67: 125-138.

Lewis-Smith, R.I. \& Gimingham, C.H. (1976). Classification of cryptogamic communities in the maritime Antarctic. British Antarctic Survey Bulletin, 33-34: 89-122.

Lewis-Smith, RI. (2001). Plant Colonization Response to climate change in the Antarctic. Folia. Facultatis Scientiarium Naturalium Universitatis Masarykianae Brunensis, Geográica, 25: 19-33.

Ochyra, R. (1998). The moss flora of King George Island Antarctica. Cracow: Polish Academy of Sciences. 278 p.

Ochyra, R.; Lewis-Smith, R.I. \& Bednarek-Ochyra, H. (2008). The Illustrated Moss Flora of Antarctica. Cambridge: Cambridge University Press. 685 p.

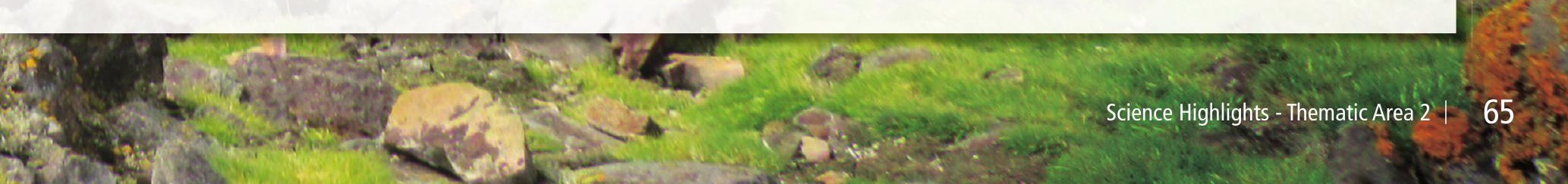


Olech, M. (1996). Human impact on terrestrial ecosystems in West Antarctica. Proccedings of NIPR Symposium on Polar Biology, 9: 299-306.

Pereira, A.B. \& Putzke, J. (1994). Floristic composition of Stinker Point, Elephant Island, Antarctica. Korean Journal of Polar Research, 5(2): 37-47.

Putzke, J. \& Pereira, A.B. (2001). The Antarctic Mosses - With Special Reference to the South Shetland Island. Canoas - RS. Editora da ULBRA. $196 \mathrm{p}$.

Schaefer, C.E.G.R.; Dias, L.E.; Albuquerque, M.A.; Francelino, M.R.; Costa, L.M. \& Ribeiro, J.R.E.S. (2004). Monitoramento ambiental e avaliação dos impactos nos ecossistemas terrestres da Antártica Marítima: Princípios e aplicação. In: Schaefer, C.E.G.R.; Simas, F.N.B. \& Albuquerque Filho, M.R. (Eds.). Ecossistemas costeiros e monitoramento ambiental da Antártica Marítima. Baía do Almirantado, Ilha Rei George. Viçosa: NEPUT. p. 107-117.

Victoria, F.C. \& Pereira, A.B. (2007). Índice de valor ecológico (IES) como ferramenta para estudos fitossociológicos e conservação das espécies de musgos na Baia do Almirantado, Ilha Rei George, Antártica Marítima. Oecologia Brasiliensis, 11(1): 50-55.

Victoria, F.C.; Albuquerque, M.P. \& Pereira, A.B. (2006). Lichen-moss association in plant comunnities of the Southwest Admiralty Bay, King George Island, Antarctica. Neotropical Biology Conservation, 1(2): 84-89.

Victoria, F.C.; Pereira, A.B. \& Costa, D.P. (2009). Composition and distribution of mos formations in the ice-free areas adjoining the Arctowski region, Admiralty Bay, King George Island, Antarctica. Iheringia Série Botânica, 64(1): 81-91.

Victoria, F.C.; Albuquerque, M.P. \& Pereira, A.B. (2011). Conservation status of plant communities in Ulmann Point and Comandante Ferraz Station area, Admiralty Bay, King George Island, Antarctica, based in the index of ecological significance. Annual Activity Report 2010. INCT-APA/ CNPq. p. 62-72. 